\title{
Implementing Prior Judicial Decisions as Precedents: The Context of Application and Justification
}

\author{
Leszek Leszczyński ${ }^{1}$
}

Published online: 17 October 2019

(c) The Author(s) 2019

\begin{abstract}
The paper concerns the conditions and methods of using previous judicial decisions as a kind of precedents in the processes of application of law within the statutory legal order. The use of such decisions, not announced by the legislator, depends on the courts, undertaking such actions on the grounds of similarity of cases or of decisional processes. Such decisions do not become an exclusive validation argument and may create a situation of their potential conflict with legal regulations as well as an inferential supplementation of their content. Dissemination of such activity of the courts leads to the development of precedential practice (relevant to the statutory legal order), though, its actual jurisdictional role depends on proper justification of decisions, within which reference to these decisions should be adaptive (in relation to the elements of the current case), generalizing (forming elements of ratio decidendi) as well as argumentative and discursive (in respect of the way in which the decisional reasoning and arguments expressed in the prior justification are used).
\end{abstract}

Keywords Prior judicial decision · Precedent · Validation argument · Application and justification of decision

The primary role of legal regulations as the source of law in the civil (statutory) law orders does not question a multi-level structure of the "carriers of law" in the course of operative interpretation of law which constitutes the basis of decisions concerning the application of law. The catalogue of such sources (carriers) also includes open clauses and prior judicial decisions.

The paper has been prepared as an effect of the research Grant "Potential of Precedent Argumentation in the Polish Legal Order (A Theoretical and Comparative Approach)", No. 2013/11/B/HS5/03821, financed by the National Science Center (Narodowe Centrum Nauki) in Poland.

Leszek Leszczyński

lex525@wp.pl

1 Chair of Theory and Philosophy, Faculty of Law and Administration, Maria Curie-Sklodowska University, Pl. M.Curie-Sklodowskiej 5, 20-031 Lublin, Poland 
Contrary to the "open texture" criteria indicated by the legislator in the form of general clauses, references to prior decisions are not announced so to speak by the legislator by way of relevant authorisation. Whether prior decisions are used or not largely depends on the composition of the adjudicating bench, in view of the fact that such a procedure is not prohibited by the law. This approach is generally accepted on all levels of the judiciary, including the highest court instances and may contribute to developing precedential practice. ${ }^{1}$

\section{Reference to Prior Decisions (A Theoretical Approach)}

1 In order to determine the role of prior decisions as validation arguments, it is essential to pinpoint the precise moment in which a reference to a prior decision is made in the decision making process.

Arguably, the first encounter of the court with the case, which leads to the identification of its legal nature and its axiological weight (a case worthy of legal protection) will entail making references to legal regulations as well as to the judicial practice even if the latter, and a specific judicial decision in particular, will not play a major role in such initial considerations.

The factor which determines whether to consider the application of a prior decision (judgment) is its presence in the material of the case under adjudication. This may indicate the presence of such a decision in the application which triggers the decision making process or in other motions filed in the course of court proceedings. This may well mean the inclusion of a prior decision in the substantiation to the decision making process currently in progress.

Absence of references to other decisions in motions or in the substantiation of a decision moves the contemplation of the application of another decision somewhat deeper in the decision making process and making it dependent on the determination of a need for such a validation measure exclusively on the basis of the findings of the court itself. Lack of any references to a prior decision on the part of the decision maker cannot, in principle, constitute grounds for a negative reaction within the terms of reference of managing this process. On the contrary, a negative reaction may be triggered by the presence of a decision in any of the forms specified above, albeit the conclusions of the decision may also depend on other factors including the degree of similarity of adjudicated matters and the degree to which the decision that is not taken into account can be utilised for the sake of the current decision making process.

While the obligation of the decision maker to build a complete set of sources (carriers) of law refers primarily to proper selection and application of legal regulations,

\footnotetext{
${ }^{1}$ Understanding precedent as "An adjudged case or decision of a court, considered as furnishing an example or authority for identical or similar case afterwards arising or a similar question of law" [7: 1176 or as "...decision that functions as a model for later decisions" [25: 1] or as "decision... that has a special legal significance... being regarded as having practical ... authority over the content of the law" [20: 1-2] as well as "decision which serves as a guide for present action [12:1].
} 
it also covers the inclusion of relevant prior decisions. These decisions do not have to take the form of binding resolutions passed by extended adjudicating boards whose presence in terms of judicial scrutiny causes a similar effect to the doctrine of stare decisis in common law, cf. [28].

2. Generally speaking, a prior decision implemented in a current decision process may function in judicial practice as an autonomous or non-autonomous argument.

Contrary to common law [9, 15], [16: 172-193], ${ }^{2}$ in codified law the autonomous validation role of prior judgments is rather hard to ascertain. Such judgments come to the fore at the judicial interpretation stage and are intertwined with legal provisions and, potentially, with the open criteria formed in general referral clauses. Together they affect, albeit to a different degree, the content of the reconstructed pattern of conduct and the normative basis for the decision, and as such they constitute a set of interpretation sources. In principle, the role of prior judgments in codified law is to supplement the set of validation arguments which contains legal provisions. ${ }^{3}$

The implementation of prior decisions alongside legal provisions usually appears once pertinent legal provisions have been identified (specifically those which are crucial to a given decision-making process). This is the time when the court finds it expedient to use prior reasoning as to the manner of applying legal provisions or that such legal provisions alone will not suffice to determine the complete normative basis for the judgment in question. This is particularly pertinent in the context of determining procedural and substantive law bases as it may happen that in the absence of relevant legal provisions in unsettled areas of the law, references can be made not so much to another provision (per analogiam legis) but to a prior court decision.

An assumption under which it is possible to supplement the reasoning based on legal provisions with the arguments deriving from prior decisions means that the presence of a relevant prior decision must be ascertained and then formally identified and approved in terms of its content as an element of adjudication. The latter component means, in turn, that the implementation of a prior decision is preceded with the preliminary reconstruction of its content and the preliminary analysis of the key legal provisions applied thereto to justify the need for making a reference to the prior decision.

3. The aforementioned prerequisites to implementing prior judicial decisions as a validation argument refer to a situation where there exists at least one such decision

\footnotetext{
2 On the relation between legislatures and judicatures see [5: 93-95, 141-143, 231-235].

3 The position of prior judicial decision was taken into consideration in Polish legal theory in $\mathrm{J}$ Wróblewski's proposed distinction between the normative basis and the decision rule, but it was listed together with the remaining elements under the decision rule and not under the normative basis [42: 7 , esp. 14-16], see also [43: $107 \mathrm{ff}$.]. The judicial precedent-linked directly with customs and indirectly with other elements-has its place in the conception of sources of law as proposed by Z. Ziembiński [46:83 ff.]. This does not mean however that a prior decision appears as a separate argument in the present theoretical models of interpretation based on legal provisions (see e.g. M. Zieliński [45: $316 \mathrm{ff}$.]; on p. 332 judicial decisions, on a par with science, are treated solely as a source of precise definitions of a normative phrase). It is treated as such where interpretation is subjected to validation and derivative analysis (see Leszczyński [22: 114-120]). See also: Morawski [27: 4].
} 
that can serve in the validation process. When reasoning is based on one decision, it is easier to determine the similarity between the two matters in question, and it also helps establish the link on the basis of which the ratio decidendi principle can be applied. Naturally, this is never tantamount to automatism in the decision-making process. When several decisions are brought to the fore, direct relations are weakened, since the matter under consideration is juxtaposed with a few different matters, and this, in turn, increases leeway to classify similarities. In effect, there may be significant differences in justify relevant links. With the application of a single prior decision, it is far easier to indicate the relevant content (quotation, elaboration, etc.). Making references to several prior decisions is likely to produce a more general and less case-specific argumentation.

That said, the essence of implementation of prior decisions remains unchanged and topical whether the references are made to judgments of national-international or supranational courts or whether judgments referred to come from higher instance courts, (most frequently supreme courts), courts of equal status or lower instance courts. The latter happens far less frequently, though. The matter of implementation looks differently only when a reference is made to a resolution, and a resolution adopted by an extended bench in particular. This is so not only because of the binding nature of such a resolution but also because of the general nature of the argumentation used and, by extension, because of the lack of direct link with a given instant case.

4. The validation function of prior judicial decisions (administrative decisions do not serve this function) should be perceived in a model statutory law system as supplementary in nature to binding legal provisions. It follows that at this point of the process functional rules of interpretation which specify the implementation of prior decisions are employed. However, these rules do not go beyond their supplementary and verifying function with respect to structural rules of the whole system linked with the application of legal provisions as the dominant source of law in this system. Functional rules may appear at this stage irrespective of axiological aspects of pragmatic interpretation where references to prior decisions and decision making processes are linked with the application of law or open criteria.

\section{Determinants of Applications}

The mere fact of implementing prior decisions is also based, besides the afore mentioned insufficiency of legal provisions, on the fulfilment of other additional criteria determined by the political and social environment of law as well as jurisdiction of the courts and judicial practice itself. The former cover social consent and the principles of the political system (separation of powers, rule of law or genuine independence of the judiciary). The latter indicate the "readiness" of judicial practice to use its own output, and play a significant role in determining the potential of applying precedents in a statutory law system. Taken together, they determine the actual use of previous judicial decisions and define the potential of harnessing precedents in statutory law systems. 
The implementation of prior decisions is further reinforced where normative regulations are blurred, where general referral clauses appear or where social changes are profound. Blurred definitions translate into more robust judicial practice which delineates the actual application of laws.

Irrespective of the factors mentioned above, at the root of the implementation of prior decisions lies a strong conviction of the bench that a prior decision should be called in especially when there is a similarity determined with respect to the factual circumstances and the circumstances ascertained while ruling in the case that is referred to, i.e. a similarity between the precedent decision and the decision at hand as well as a similarity in the reasoning employed in both cases analysed.

\subsection{Similarity of Cases or Decision-Making Processes}

The similarity between decision making processes in prior and current decisions may be seen primarily in three aspects.

Firstly, this similarity may (and it does happen most frequently) be seen in the similarity of factual circumstances ascertained in the two proceedings, cf. [26: 504-510], [36: $87 \mathrm{ff}$.]. Secondly, the similarity may be perceived in significant elements of the legal status in both cases (e.g. in the legal institution which the decision making process refers to). Thirdly, there may exist a similarity between a significant element of the reasoning process (operative interpretation that establishes substantive law, procedural or competence-related grounds).

In all three judicial circumstances the reasoning which aims at capitalising on a prior decision is, in a sense, similar to the per analogiam legis reasoning. ${ }^{4}$ By making references to legal provisions, notably in statutory law systems, where relevant regulations are missing, this type of reasoning examines a similarity between the elements of both factual circumstances or legal institutions, which makes it possible to apply a legal provision (its element or a few provisions that are somehow related to each other in terms of the subject matter) that has been omitted in the decision making process concerning the matter in question. In this context, the per analogiam legis reasoning can be shown as the "per analogiam decisionis" reasoning provided that the latter, largely based on similarities, focuses not so much on the rule contained in the provision but on the ratio included in another decision.

Universal application of the two models of reasoning is yet another matter. While the application of per analogiam legis denotes an indirect (quasi-inferential) application or use of legal provisions, the reasoning based on per analogiam decisionis is proper reasoning behind the use of any prior decision in the current law application process. Consequently, this reasoning implements prior decisions directly irrespective of the fact that it supplements the reconstructed model of a legal provision rather than fills in the judicial void by providing the missing decision. Consequently,

\footnotetext{
${ }^{4}$ Cf.: The presence of per analogiam reasoning may determine a non-illustrative nature of the judicial precedent (see the contributions gathered in thebook "Interpreting Precedent. A Comparative Study", ed. N.D. MacCormick, R.S. Summers, Dartmouth 1997—[3:50], [34:282], [40:172], [41: 130] and see also [30].
} 
for the needs of the decision making process at hand, the distinction between basic decisions (which have the strongest link with the subject matter in question) and supplementary decisions may actually lead to a relative distinction between direct and indirect implementation or use of a prior decision.

The similarity of factual circumstances, which is related to the two types of analogy, exposes, in fact, the most noticeable difference between them. ${ }^{5}$ While the factual circumstances ascertained in a current decision making process are specific, the factual circumstances confronted or juxtaposed within the terms of reference of the per analogiam legis reasoning are "regulated" factual circumstances (generally identified on the level of normative regulations), and not linked to a specific decision making process. The latter circumstances occur so to speak in the form imagined by the current decision maker (through the identification of their components) or in the form made up of specific circumstances which occur in many decision making processes in which a given provision is applied per analogiam.

Such a distinction of the specific nature of factual circumstances does not occur in the per analogiam decisionis reasoning employed in the judicial precedent model, which, as it has been shown above, consists in utilising the content of a prior decision or the arguments used in its substantiation. This difference comes from the fact that factual circumstances in this case have a similar level of specificity in both decision making processes in order to provide their final classification within the terms of reference of the normative basis of the decision. In this sense, the similarity, which determines the use of the per analogiam reasoning with respect to a prior decision comes from the comparable specificity of factual circumstances ascertained.

The prerequisite indicated above concerning the similarity of factual circumstances should be extended to cover the practice of implementing prior decisions during the decision making processes where phenomena of the material world (actions, deeds, and/or omissions) are not determined but where such the objects of phenomena have legal elements (e.g. an act within the framework of determining the constitutionality of legislation, administrative decision within the framework of judicial review of legality of measures taken by the administration, or judgment within the framework of cassation scrutiny by a higher court). The prerequisite of similarity should then cover the similarity of a judicially reviewed provision of a statutory act, decision, resolution or judgment which are subject to normative classification with the same provisions, decisions, and judgments that constituted the legal elements of prior decisions.

A similarity between legal institutions or other legal constructs (e.g. types of blanket provisions or program norms) to which references are made in prior and current decisions can also constitute the grounds for implementing prior decisions. Here the scope of such a similarity is general where normative regulations are concerned and specific where they refer to the content of interpretation reasoning behind prior decisions implemented.

\footnotetext{
5 More on the role of analogy in precedential practice can be found in [14: 96-101], [19: $147 \mathrm{ff}$.$] , [23:$ 138-174], [32: 1 ff.], [36: 91 ff.], [38: 99 ff.].
} 
That said, similarities between institutions, normative constructs, and interpretations can be shaped not only through the properties of normative regulations but also through long-term judicial practice. This, however, does not have a significant effect on the treatment of the argument based on similarity in the context of determining the generality and specificity of the elements that constitute the decision making processes. Such an assertion also refers to the similar stability of these features. Where the practice that shapes these features is adequately long, the effects generated are similar to those generated by the law making activity, and in some cases, notably where strong law-making traditions are evoked, this practice shapes said features in a more durable manner than the current law-making policy. Naturally, there are other political system-related considerations that influence precedentrelated practice.

\subsection{Intention of the Court}

Similarities between factual circumstances, legal institutions, normative constructs or judicial reasoning become real where a specific court (judicial bench) ${ }^{6}$ demonstrates its conviction and intention which stem from the asserted needs to make a decision (always in the context of its own decision). This constitutes the basis for the determination of direction and scope of implementation of prior decisions as falling within a given judicial practice, as supplementing or disputing (usually in part) the same.

The absence of the stare decisis rule in the statutory law systems shifts the implementation of prior decisions from the category of 'obligation' to the category of 'need' (in the context of correctness and functionality of the decision making process). A disparate situation, and different from the doctrine of judicial precedent on which a common law system rests, occurs in a statutory law system where the implementation of a prior decision stems from its binding nature of (a) judgments of the constitutional court on the constitutionality of an act claimed to be in conflict with the constitution), (b) resolutions passed by an extended bench of the Supreme Court), and (c) implementation of a decision to reverse judgment of a court of higher instance by the court which reconsiders a given matter).

One should not rule out, notably in the case of decisions passed by lower courts, some degree of 'opportunistic anticipation of a review' by a higher instance court as a factor which determines references to a previous decision. Nevertheless, the intention of a specific composition of the bench is largely based on ascertaining a need to make a decision, as mentioned above (notably where relevant bodies must take a decision as part of a binding procedure). This, in turn, give rise to a strong conviction that without a recourse to a prior decision, the decision-making process or the decision currently made would simply be flawed.

This conviction is also linked with a shift of responsibility for the inclusion of prior decisions and use of the same in passing the judgment at hand onto a relevant

\footnotetext{
${ }^{6}$ For more information on the role of justices in the manner of their ruling see: [29: 335-338], [31: 215 ff.].
} 
composition of the bench. Even when parties to litigation point out prior decisions as relevant to the matter in question, the responsibility for the decision to include prior decisions remains unchanged and rests with the bench. The same applies where argumentation presented in the substantiation of the decision makes references to prior decisions.

The intention of the judicial bench is of utmost importance, ${ }^{7}$ but it is 'just' a preliminary step. Besides the required similarity of decision-making cases, as shown above, it is important to add the feasibility of identifying the content and the employment of ratio decidendi of the prior decision to the decision-making process at hand. This, however, is linked with the reconstruction of the norm applied to the prior decision and identifying its role in developing the normative basis for the decision at hand.

\subsection{Some Optimizing Factors}

An attempt at developing a model which optimises judicial practice of implementing prior decisions, which, in its essence, would enrich this model with certain characteristics of a judicial precedent-based practice (within the limits accepted in a statutory law system), could operate around four basic components. And these, in turn, depend on the maturity and the level of expertise of court jurisdiction. These elements refer to the time and the grounds for considering a need to resort to a prior decision, to establishing links between the implementation of a prior decision with the binding provisions of the law, and to the type of prior decisions which is referred to in a decision-making process at hand.

Firstly, the question concerning possible implementation of a prior decision or decisions should be asked relatively early on in the course of the decision-making process. Such consideration may not necessarily exclude the question of resorting to prior decisions with a view to determining the nature of the matter that requires legal protection during the initial discovery. At this stage sources for the reconstruction of the norm/norms to be applied are selected. Assuming that the first stage is all about the identification of legal provisions (relating to competences, procedures, and substantive law), the object of the matter should always be 'located' (without making a decision about the manner in which it is to be used) within the general framework of jurisprudence and then in the context of the content of specific decisions which are relevant to the decision-making process at hand.

Secondly, the decision-making process should employ such decisions which are 'required' irrespective of whether they have been indicated in the claims of the parties or not and, with respect to revision processes, whether they have appeared in the reviewed decision or not. Maintaining full discretion of the court as to the implementation of prior decisions and determination of similarity between the relevant matters (in terms of factual circumstances and legal status) is of primary

7 This also pertains to a common law system (Cf.: [2: 46-49]). 
importance. The latter should help the court distinguish between primary decisions (of key importance to the decision-making process) and secondary or auxiliary in nature.

Indicating "a decision for implementation" pertaining to a specific element of the current decision-making process by a party to litigation reinforces the link between the referential decision and the one to be made (especially where such a decision is pointed out by more than just one party involved). This should lead to considering the motions which refer to prior decisions. The presence of such arguments in the initial claim or in the 'reply' to this motion directs the attention of the court to the entire decision-making process. The presence of such arguments during the course of litigation will usually indicate partial links between its elements and the elements of the judicial precedent.

The same can be said about the requirement to assess the applicability of prior decisions brought to the fore and adapted as part and parcel of the arguments developed in the substantiation (justification) to the decision under review of a higher instance court (irrespective of the manner of such a review). The 'jurisdictional obligation' which is thus established allows for a more precise placement of the current decision under review within the framework of juridical practice or even the entire jurisprudence.

Thirdly, a search for 'an applicable decision' undertaken in a similar decisionmaking situation should be based on an assumption that such a decision will not function as an independent source of law but as a decision that supplements relevant legal provisions applied. This process of supplementing can be extended in two cases. Firstly, where an open criterion included in a referral clause becomes a validation argument (it is essential, however, to determine the content and the decision-making role of this referral clause). Secondly, where the absence of a primary provision which regulates a given matter is ascertained, which allows for filling in the gap by prior decisions in connection with general provisions, principles of law or open criteria. It should be assumed that the role of a prior decision as a validation argument is weakened in the case of looking for the sources for the reconstruction of competence rules as opposed to determining the sources for the reconstruction of procedural patterns, and those relating to substantive law in particular.

And fourthly, judicial decisions required in a current decision-making process should potentially have the broadest scope in terms of territory and court instance. Courts should not limit themselves, which is a common practice, to using their own prior decisions personally and institutionally ${ }^{8}$ or decisions made by higher courts. There are no formal grounds to eliminate the application of decisions made by courts of the same or lower instances. ${ }^{9}$ Such an open approach should also include references to the judgments of the courts of separate types of jurisdiction (e.g. the use of judgments in civil law matters in the processes of judicial review of public administration), of the courts of other states in federations as well as of the international and

\footnotetext{
${ }^{8}$ More on 'self-precedent' can be found in [1: $35 \mathrm{ff}$.]. On the role of the supreme courts' decisions see [8: $817 \mathrm{ff}]$, [18: $267 \mathrm{ff}]$, [35] and [13].

9 Different relations in this area are described in [39: $437 \mathrm{ff}$.$] .$
} 
supranational courts or of the courts in foreign countries which are culturally linked with the law applied by the court that makes such references (that is a rarer practice in statutory law systems). ${ }^{10}$

\section{Context of Justification}

The justification of the decision, especially its argumentation in writing, becomes a focal point of the maturity of judicial practice and the resulting will of a specific bench of justices as well as the efficacy of the ratio decidendi adapted for the needs of the decision making process at hand, cf. [4]: 481-502].

It is, therefore, essential that the justification of a decision be of adequate quality to allow the same to be classified as a precedent for a decision-making process at hand but also to make precedential use of such a decision as an independent thesis, supporting argument or argument which supplements previously developed theses. Such an approach will then become an element of more permanent practice. ${ }^{11}$ Upon the fulfilment of additional requirements concerning the determination of structural bonds between decisions, precedential practice in statutory law countries is likely to become its stable feature.

To make it effective, firstly, references to a prior decision or decisions should be performed not by indicating the case number or numbers of a judicial decision, which can be perceived as merely ornamental, but by delving into the argumentation disclosed in that judgment. Rather than a direct citation (which is still better than merely making a reference to the case number), such a procedure should consist in precise explanation of the argument that led to the adaptation of the prior judgment to the current decision-making process. That said, focusing not so much on many decisions but rather on one or a few decisions at the most, indicated in the jurisprudence and its evolution and specifying their relation to the decision at hand offers the largest scope for the adaptation of prior decisions.

Secondly, while applying prior decisions, it is essential to specify the degree of compatibility of decision-making situations, and to identify the ratio decidendi, properly generalised and adequately adapted (i.e. the core of the justification where the content of the final decision is presented and the rationale behind it explained). The arguments in support of a given thesis should be clearly outlined, as they usually modify the applied ratio. Finally, the extent of adaptation of the prior decision

\footnotetext{
${ }^{10}$ This rarely happens for example in the Polish legal order (see however for example the provision of the Supreme Court of Oct. 11, 2013, I CSK 697/12, in that the judgment of the US Supreme Court Exxon Shiping Company v. Grant Baker, 554 U.S.471, 2008) and judgment of the German Supreme Court of June 4, 2992, IX ZR 149/91 have been cited or the Judgment of the Constitutional Court of Nov. 24, 2010 where decision of the French Constitutional Council of Dec. 20, 2007 and judgment of the German Constitutional Court of June 6, 2001 have been cited).), but it is common practice in the AngloSaxon culture (Cf.: [17]). Also see [6, 10].

11 R.S. Summers and S. Eng discuss various approaches to precedents in court judgments in the context of departures therefrom; see [37: 519 ff.] (e.g. regarding non-overt argumentation-pp. 522-523). More on the role of justification in the context of Anglo-Saxon practise, see [11: $134 \mathrm{ff}$., specifically 137 and 146-167].
} 
or decisions to the current decision-making process should be determined also through the confrontation of its content with other sources (like the legal principles, open values, conflicting rule, etc. ${ }^{12}$ ).

Thirdly, the most effective reference to prior decisions in which links between decisions are clearly exposed is such a reference to the arguments used in the justification of a decision which reflects the decision-making reasoning (i.e. the course of reasoning, the content of arguments and their role in arriving at the decision) and the decision itself with a view to determining the degree of "repetition" of the judgment. Both these aspects require annotations to the arguments disclosed in the justification to the prior decision in the light of the current decision-making process. Such annotations should indicate why a particular prior decision is referred to and how it applies to the current one.

Fourthly, the judgment which contains arguments with references to prior decisions should be expressed in the so called discursive style. ${ }^{13}$ Generally speaking, this style combines linguistic clarity and precision in formulating one's own thesis in the context of the jurisprudence heretofore as well as a clear indication of the prior decision, reasoning behind it and arguments used which, for some reason, have not been adopted to the current decision-making process. ${ }^{14}$ Furthermore, these annotations should precisely indicate the scope, causes, and effects of implementing prior decisions, reasoning processes or arguments used in the judgment in question (also in the context of "costs and benefits" of such references).

And finally, the 'depth' of argumentation and the discursive nature of the style employed of the judgment may not thwart the general requirement of linguistic clarity and correctness. References to the arguments used in the justification of prior decisions must also encompass particular juridical precision particularly where such references are made to reasoning processes behind prior decisions as disclosed in relevant justifications. Since such a justification is to serve as the basis for future decision-making processes, the presence of properly created "juridical components" is equally essential as the communicative clarity with respect to non-professional recipients of the judgment.

\footnotetext{
${ }^{12}$ That would be an element of more complex justification, relevant for example, to D.N. MacCormick's concept of the second-order justification (see: [24: $100 \mathrm{ff}$.$] ).$

${ }^{13}$ Cf.: [47: 94 ff.]. The US Supreme Court's decision in Planned Parenthood v. Casey is an example of complete discursivity of court judgment in the context of references to prior decisions, including Roe v. Wade as well as in the context of general statements and those which refer to a justified departure from the already well established precedent (cf.: 505 US 1992, specifically pp. 854-855). Also see annotations to this decision by K. Yoshino [44: $471 \mathrm{ff}$.].

${ }^{14}$ One would, in particular expect some reference to the distinction between overruling a decision deemed as a precedent, which constitutes an established model of adjudicating in a given type of cases, and not implementing a given decision due to significant differences in the judicial decision-making situation (distinguishing or narrowing). More on references to the Anglo-Saxon practice, see [12: $111 \mathrm{ff}$.], [14: 93-96], [21: 582], [33].
} 


\section{Concluding Remarks}

Granting prior judicial decisions a specific place within the framework of validation arguments, even if this constitutes but a model for supplementing legal provisions, not only determines the course and results of subsequent stages of judicial interpretation but also changes the perception of law. On the one hand, such an approach makes the decision-making processes in statutory law countries more real and comprehensible. After all, the implementation of prior decisions in such legal systems is a fact, and the tendency continues to grow. On the other hand, taking into consideration prior decisions is a step towards departure from a strictly positivistic approach to law and its application offering the inclusion of other sources of law besides legislation.

A realistic outlook on the implementation of prior judicial decisions rests on an assumption that such decisions cannot function as independent sources of law. However, such decisions should be taken into consideration early on as the needs for expanding the set of sources for the reconstruction of a given norm dictate (i.e. going beyond legal provisions) and in the broader jurisdictional context of such prior decisions. If the implementation of prior judicial decisions is disclosed by way of indicating a similarity between decision-making situations and adapting the content of the prior decisions to the justification of the decision at hand, it is likely that such implementations may become more common and, in turn, shape the precedential type of judicial practice.

Open Access This article is distributed under the terms of the Creative Commons Attribution 4.0 International License (http://creativecommons.org/licenses/by/4.0/), which permits unrestricted use, distribution, and reproduction in any medium, provided you give appropriate credit to the original author(s) and the source, provide a link to the Creative Commons license, and indicate if changes were made.

\section{References}

1. Abellan, Marina Gascón. 2012. Rationality and (self)precedent: Brief remarks concerning the grounding and implications of the rule of precedent. Archiv fur Rechts- und Sozialphilosophie 133: 35-51.

2. Alexander, Larry, and Emily Sherwin. 2007. Judges as rule makers. In Common Law Theory, ed. Douglas E. Edlin. Cambridge: Cambridge University Press.

3. Alexy, Robert, and Ralf Drier. 1998. Precedent in Germany. In Interpreting Precedent. A Comparative Study, ed. D. Neil MacCormick and Robert S. Summers. Aldershot: Dartmouth.

4. Bankowski, Zenon, D.Neil MacCormick, Lech Morawski, and Ruiz Alfonso. 1998. Rationales for precedent. In Interpreting Precedent. A Comparative Study, ed. D. Neil MacCormick and Robert S. Summers. Aldershot: Dartmouth.

5. Barak, Aharon. 2008. The Judge in a Democracy. Princeton: Princeton University Press.

6. Bertea, Stefano, and Claudio Sarra. 2015. Foreign Precedents in Judicial Argument: A Theoretical Account. European Journal of Legal Studies 7. Retrieved on 25 October 2017 from http://www.ejls. eu/16/199UK.htm.

7. Black, Henry Campell. 1990. Black's Law Dictionary, 6th ed. St. Paul: West.

8. Caminker, Evan H. 1994. Why must inferior courts obey superior court precedents. Stanford Law Review 46 (4): 817-873.

9. Cross, Rupert. 1968. Precedent in English Law. Oxford: Clarendon Press. 
10. Drobnig, Ulrich, and Seth Van Erp. 1994. The use of comparative law by courts. In XIV World Congress of Comparative Law. Athens

11. Dyzenhaus, David, and Michael Taggart. 2007. Reasoned decisions and legal theory. In Common Law Theory, ed. Douglas E. Edlin. Cambridge: Cambridge University Press.

12. Duxbury, Neil. 2008. The Nature and Authority of Precedent. Cambridge: Cambridge University Press.

13. Edmundson, William A. 2007. Schauer on precedent in the U.S. Supreme Court. Georgia State University Law Review 24 (2): 403.

14. Eisenberg, Melvin A. 2007. The principles of legal reasoning in the common law. In Common Law Theory, ed. D.E. Edlin. Cambridge: Cambridge University Press.

15. Gerhardt, Michael J. 2008. The Power of Precedent. Oxford: Oxford University Press.

16. Goodhart, Arthur L. 1930. Case law in England and America. Cornell Law Quarterly 15 (2): 173.

17. Groppi, Tania, and Marie-Claire Ponthoreau (eds.). 2013. The Use of Foreign Precedents by Constitutional Judges. Oxford: Hart.

18. Harding, Matthew, and Ian Malkin. 2012. The High Court of Australia's obiter dicta and decisionmaking in the lower courts. Sydney Law Review 34 (2): 240.

19. Koszowski, Maciej. 2016. The Scope of application of analogical reasoning in precedential law. Law and Forensic Science 11: 19.

20. Lamond, Grant. 2006. Precedent and analogy in legal reasoning. The Stanford Encyclopedia of Philosophy. Retrieved on 20 October 2016 from http://plato.stanford.edu/entries/legal-reas-prec/.

21. Lee III, and G. Emery. 2002. Overruling rhetoric: The court's new approach to stare decisis in constitutional cases. University of Toledo Law Review 33: 581.

22. Leszczyński, Leszek. 2000. Zagadnienia teorii stosowania prawa. Doktryna i tezy orzecznictwa, Kraków: Kantor Wydaw.

23. Levin, Joel. 1992. How Judges Reason. New York: The Logic of Adjudication.

24. MacCormick, Neil. 1978. Legal Reasoning and Legal Theory. Oxford: Clarendon Press.

25. MacCormick, Neil, and Robert S. Summers. 1998. Introduction. In Interpreting Precedent. A Comparative Study, ed. D. Neil MacCormick and Robert S. Summers. Aldershot: Dartmouth.

26. Marshall, Geoffrey. 1998. What is binding in a precedent. In Interpreting Precedent. A Comparative Study, ed. D. Neil MacCormick and Robert S. Summers. Aldershot: Dartmouth.

27. Morawski, Lech. 1996. Precedens a wyktadnia. Państwo i Prawo 10 (4): 3-5.

28. Moschzisher, Robert von. 1924. Stare decisis in courts of last resort. Harvard Law Review 37: 409-430.

29. Nash, Jonathan Remy, and Rafael I. Pardo. 2013. Rethinking the principal-agent theory of judging. Iowa Law Review 99 (1): 331.

30. Nowacki, Józef. 1966. Analogia legis. Warszawa: PWN.

31. Perry, Stephen R. 1987. Judicial obligation, precedent and the common law. Oxford Journal of Legal Studies 7: 215-257.

32. Postema, J.Gerald. 2007. A similibus ad similia: analogical thinking in law. In Common Law Theory, ed. D. Douglas and E. Edlin. Cambridge: Cambridge University Press.

33. Re, Richard M. 2014. Narrowing precedent in the supreme court. Columbia Law Review 114: 1861-1911.

34. Ruiz, Miguel Alfonso, and Francisco J. Laporta. 1998. Precedent in Spain. In Interpreting Precedent. A Comparative Study, ed. D. Neil MacCormick and Robert S. Summers. Aldershot: Dartmouth.

35. Segall, E.J. 2011. Is the Roberts Court really a court? Stetson Law Review 40: 701.

36. Sitala, Raimo. 2000. A Theory of Precedent. From Analytical Positivism to a Post-Analytical Philosophy of Law. Oxford: Hart.

37. Summers, Robert S., and Svein Eng. 1998. Departures from precedent. In Interpreting Precedent. A Comparative Study, ed. D. Neil MacCormick and Robert S. Summers. Aldershot: Dartmouth.

38. Stone Sweet, Alec, and Margaret McCown. 2003. Discretion and precedent in European law. In Judicial Discretion in European Perspective, ed. Ola Wiklund. Stockholm: Kluwer Law International.

39. Taruffo, Michelle. 1997. Institutional factors influencing precedents. In Interpreting Precedent. A Comparative Study, ed. D. Neil MacCormick and Robert S. Summers. Aldershot: Dartmouth.

40. Taruffo, Michelle, and Massim La Torre. 1999. Precedent in Italy. In Interpreting Precedent. A Comparative Study, ed. D. Neil MacCormick and Robert S. Summers. Aldershot: Dartmouth.

41. Troper, Michel, and Christopher Grzegorczyk. 1998. Precedent in France. In Interpreting Precedent. A Comparative Study, ed. D. Neil MacCormick and Robert S. Summers. Aldershot: Dartmouth. 
42. Wróblewski, Jerzy.1969. Podstawa normatywna i reguła decyzji w sądowym stosowaniu prawa. Studia Prawno-Ekonomiczne III.

43. Wróblewski, Jerzy. 1988. Sadowe Stosowanie Prawa. Warszawa: PWN.

44. Yoshino, Kenji. 1994. What's past is prologue: Precedent in literature and law. The Yale Law Journal 104: 471.

45. Zieliński, Maciej. 2006. Wykładnia Prawa. Zasady, Reguły, Wskazówki. Warszawa: Wolters Kluwer.

46. Ziembiński, Zygmunt. 1974. Teoria Prawa. Warszawa-Poznań: PWN.

47. Zirk-Sadowski, Marek. 2005. Wykładnia i rozumienie prawa w Polsce po akcesji do Unii Europejskiej. In Polska kultura prawna a proces integracji europejskiej, ed. Sławomira Wronkowska. Kraków: Zakamycze.

Publisher's Note Springer Nature remains neutral with regard to jurisdictional claims in published maps and institutional affiliations. 